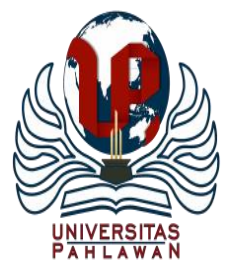

Edukatif : Jurnal Ilmu Pendidikan Volume 3 Nomor 6 Tahun 2021 Halm 3593 - 3601

EDUKATIF: JURNAL ILMU PENDIDIKAN

Research \& Learning in Education

https://edukatif.org/index.php/edukatif/index

\title{
Pengembangan Media Video Animasi untuk Kemampuan Menghafal Hadist pada Anak Usia Dini
}

\author{
Siti Zahara ${ }^{1 凶}$, Benny Hendriana ${ }^{2}$ \\ Universitas Muhammadiyah Prof. Dr. Hamka, Indonesia ${ }^{1,2}$ \\ E-mail : zaharamabet25@gmail.com ${ }^{1}$, benny_hendriana@uhamka.ac.id ${ }^{2}$
}

\begin{abstract}
Abstrak
Tujuan dari penelitian ini adalah untuk mengembangkan media pembelajaran video animasi untuk kemampuan menghafal hadsit pada anak usia dini di TAAM/TPQ AL-ANWAR Depok Jawa Barat guna meningkatkan dalam menghafal hadist beserta gerakan. Jenis metode ini adalah R\&D (Research And Development) dengan model pengembangan ADDIE. Penilaian uji validitas berdasarkan dari para ahli, pendidik TAAM/TPQ ALANWAR, dan orang tua siswa kelompok B TAAM/TPQ AL-ANWAR Depok Jawa Barat. Hasil rata-rata penilaian olehahli media sebesar $90 \%$ dengan kategori sangat valid, ahli materi sebesar $100 \%$ dengan kategori sangat valid, serta ahli bahasa dengan rata-rata sebesar $87 \%$ dengan kategori sangat valid. Hasil yang diuji cobakan terhadap pendidik TAAM/TPQ AL-ANWAR rata- rata sebesar 77\% dengan kategori valid dan orang tua peserta didik kelompok B TAAM/TPQ AL-ANWAR rata-rata sebesar 86,6\% dengan kategori sangat valid. Dari hasil penelitian tersebut, maka peneliti menyimpulkan bahwa pengembangan media video animasi menghafal hadist pada anak sangat layak digunakan dalam proses belajar mengajar di TAAM/TPQ ALANWAR Depok Jawa Barat.
\end{abstract}

Kata Kunci : Gerakan, Hafalan Hadist, Media Video Animasi.

\section{Abstract}

The purpose of this study was to develop an animated video learning media for the ability to memorize hadith in early childhood at TAAM/TPQ AL-ANWAR Depok, West Jawa, in order to used by the researcher is $R \& D$ (Research And Development) with the ADDIE development model. The validity test was assessed based on media experts, material experts, linguists, TAAM/TPQ AL-ANWAR Depok, West Jawa. The results of the percentage of media experts are $90 \%$ in the very valid category, the presentation of material experts is $100 \%$ in the very valid category, and the percentage of linguists is $87 \%$ in the very valid category. The test results for TAAM/TPQ AL-ANWAR teachers were $77 \%$ with valid categories and $1186,6 \%$ with very valid category form these results, then it can be concluded that the animated video animasi memorizing hadith in early childhood is very valid and suitable for use in student learning at TAAM/TPQ AL-ANWAR Depok, West Java.

Keywords : Animated Video Media, Memorization of hadith, Movement.

Copyright (c) 2021 Siti Zahara, Benny Hendriana

$\triangle$ Corresponding author

Email : zaharamabet25@gmail.com

DOI : https://doi.org/10.31004/edukatif.v3i6.948

ISSN 2656-8063 (Media Cetak)

ISSN 2656-8071 (Media Online) 
3594 Pengembangan Media Video Animasi untuk Kemampuan Menghafal Hadist pada Anak Usia Dini - Siti Zahara, Benny Hendriana

DOI: https://doi.org/10.31004/edukatif.v3i6.948

\section{PENDAHULUAN}

Pendidikan Anak Usia Dini (PAUD) adalah sesuatu kegiatan dalam binaan pendidikan pada anak usia 0-6 Tahun, dengan memberikan stimulus pendidik dapat membantu tumbuh kembang anak secara fisik dan mental, sehingga peserta didik dapat mempersiapkan pendidikan dalam tahap selanjutnya (Indah Kemala Dewi, 2021). Pada dasarnya dunia anak ialah bermain, bermain suatu cara dapat membuat anak belajar dan mudah memahami kawasan lingkungan, kebutuhan yang sangat berguna serta mendasar untuk anak, dengan bermain anak bisa penuhi semua aspek perkembangan meliputi aspek motorik, bahasa, kognitif, sosial emosional dan moral (Nasution, 2020; Pratiwi, 2017).Pengembangan nilai moral keagaman sangat erat kaitannya dengan kepribadian anak, sikap sopan santun, dan kemauan untuk melaksanakan ajaran agama dalam kehidupan sehari-harinya (Safitri \& 'Aziz, 2019).

Pada aspek perkembangan nilai agama dan moral sangat perlu di terapkan kepada anak, karena anak usia dini (paud) berada pada masa keemasan/goolden age sehingga perkembangan otaknya masih sangat baik. menerapkan perkembangan agama moral pada peserta didik dapat membentuk dasar perilaku dan sikap didalam kehidupan yang akan datang, termasuk pada masa kecil, remaja, dewasa dan masa orang tua (Tanfidiyah, 2017) .Agama memiliki peranan penting bagi di dalam kehidupan umat manusia, karena agama adalah salah satu acuan untuk mewujudkan kehidupan yang bermakna, maka dari itu kehidupan umat manusia di dalam kehidupan setiap masing-masing individu yang ditempuh melalui pendidikan yang baik didalam lingkungan keluarga, sekolah dan masyarakat. Pendidikan agama dapat membentuk karakter anak agar menjadi lebih taqwa serta memahami ajaran yang di perintahkan oleh Allah SWTsalah satunya dengan menghafal alqur'an dan hadits (Adriasa, 2021).

Permasalahan anak dalam menghafal adalah kurangnya perhatian dari guru sehinga proses menghafalnya pun terhambat atau kurang konsisten, menghafal juga tidak mudah seperti membalik telapak tangan, salah satu faktor mengalami kesulitan menghafal adalah kurangnya persiapan dari anak sehingga mereka sulit dalam menghafal (Oktapiani, 2020; Silawati \& Syukri, n.d.). Aktivitas menghafal merupakan suatu kegiatan yang menerapkan suatu pembelajaran melalui proses verbal serta menyimpan didalam sebuah ingatannya, sehingga bisa menciptakan kembali kealam sadar (Riqqoh, Syaiku, \& Mappapoleonro, 2020).

Peneliti telah melakukan wawancara dengan guru di TAAM/TPQ AL-ANWAR Depok Jawa Barat. Berdasarkan hasil wawancara yang telah dilakukan oleh peneliti pada lembaga tersebut, media untuk pembelajaran menghafal hadist masih belum berkembang dikarenakan proses menghafal hadist dengan gerakan masih tergolong minim, serta banyak guru yang belum hafal dengan hadist beserta gerakannya. Sehingga anak belum mampu menghafalkan hadist dengan sebuah gerakan karena metode pembelajaran yang digunakan oleh guru tidak menarik. Jadi membuat anak mudah lupa dan bosan dalam menghafal hadist dengan gerakannya.Maka dengan itu peneliti merancang sebuahmedia pembelajaran yaitu berbasis video animasi yang dapat merangsang kembali semangat anak dalam menghafal hadist beserta gerakannya.

Media pembelajaran merupakan faktor yang sangat penting dalam proses pembelajaran, guru juga harus menggunakan media sebagai bahan ajar untuk meyampaikan materi kepada siswa, karenga dengan menggunakan media akan dipahami oleh siswa dengan baik, salah satu media yang baik untuk digunakan adalah media video animasi (Wahyuningtyas \& Sulasmono, 2020). Video animasi adalah suatu media audio visual yang dirangkai melalui proses penciptaan efek gerak atau perubahan bentuk sehingga menampilkan gambar berurutan membuat penonton merasakan adanya ilustrasi pada gambar yang ditampilkan. Media pembelajaran video animasi dapat menyajikan objek secara rinci serta dapat menunjang dalam menguasi pembelajaran ,dan dapat dimanfaatkan untuk penyampaian materi kepada anak dengan cara yang menyenangkan sehingga anaktidak mudah bosan dan jenuh (Ani Wahyuni, Rame Santoso, \& Sidik, 2019; Apriansyah, 2020; JANNAH \& JULIANTO, 2018). 
Salah satu media yang efektif proses dalam pembelajaran anak usia dini yaitu adalah media yang menarik tidak membosankan dan bisa disesuaikan dengan usia anak, media tersebuat adalah media animasi, karena animasi serangkaian gambar atau tulisan yang diatur secara beraturan dengan aturan tertentu sehingga menghasilkan gambar yang bergerak (Anita Puji Astutik, Rahmania Sri Untari, 2021).

Pembelajaran media video animasi menghafal hadist dengan gerakan dapat membantu anak-anak dalam meningkatkan cara menghafal hadist dengan cepat dan mudah diusia dini. Dalam pengembangan media video animasi peneliti akan mencoba menyajikan kumpulan hadist sehari-hari yaitu seperti hadist larangan marah serta dengan tulisan arab dan terjemahannya. Seperti penelitian yang telah dilakukan oleh (Malikhah, 2019) menyatakan hasil penelitiannya bahwa media pembelajaran menghafal hadist melalui metode gerakan layak untuk digunakan dan diterapkan dikehidupan sehari-hari.

Selanjutnya penelitian terdahulu yang pernah dilakukan oleh (Riqqoh et al., 2020) menyatakan hasil penelitiannya bahwa mengahafal hadist melalui 5M (membacakan, mendengarkan, menirukan, menghafal dan menggerakkan). Penelitian terdahulu yang pernah dilakukan oleh (Anita Puji Astutik, Rahmania Sri Untari, 2021) menyatakan hasil penelitiannya bahwa menghafal muroja'ah for kids menggunakan media animasi lebih efektif dan menarik untuk anak dalam menghafal. Dari hasil penelitian terlebih dahulu peneliti belum menemukan adanya sebuah penelitian berupa pengembangan media video animasi untuk meningkatkan kemampuan anak dalam menghafal hadist. Maka dari itu peneliti memiliki keyakinan bahwa video animasi yang di kembangkan akan efektif dan layak digunakan sebagai media pembelajaran untuk anak usia dini. untuk mengembangkan sebuah media pembelajaran video animasi untuk kemampuan menghafal hadist pada anak usia dini.

\section{METODE PENELITIAN}

Metode penelitian ini adalah pengembangan Research And Development (R\&D) dengan model pengembangan ADDIE. Model penelitian ADDIE dalam penelitian ini berdasarkan atas pertimbangan bahwa model ini menghasilkan suau produk yang disusun secara sederhana dengan sistematis membuat model desain ini mudah dipahami serta lebih efektif untuk diaplikasikan. Langkah-langkah dalam pengembangan model ADDIE terdiri dari lima langkah yaitu : analysis, design, development, implementation, evaluation. Penelitian ini dilaksanakan di TAAM /TPQ AL-ANWAR Depok Jawa Barat, dengan subjek penelitian yaitu anak berusia 5-6 tahun. Teknik pengumpulan data pada penelitian ini menggunakan teknik pengumpulan data dengan angket/kuesioner. Pengumpulan data tersebut digunakan dengan cara menyebarkan angket/ kuesioner secara online melalui google formulir. Teknik analisis menggunakan teknik analisis statistik deskriptif dalam bentuk deskriptif presentase. Kriteria penilaian angket sebagai berikut :

Tabel. 1 Kriteria Penilian Angket

\begin{tabular}{cc}
\hline Jawaban & Score \\
\hline Sangat Baik & 4 \\
\hline Baik & 3 \\
\hline Cukup Baik & 2 \\
\hline Tidak Baik & 1 \\
\hline
\end{tabular}

Hasil presentase score yang diperoleh ari masing-masing ahli, guru dan orang tua kelompok B kemudian dirata-ratakan kembali untuk mendapat nilai yang dapat mewakili responden. Dapat dilakukan dengan cara menjumlah keseluruhan nilai dari responden, kemudian membaginya dengan jumlah responden. Berikut kategori presntase untuk kelayakan media yang dikembangkan: 
3596 Pengembangan Media Video Animasi untuk Kemampuan Menghafal Hadist pada Anak Usia Dini - Siti Zahara, Benny Hendriana

DOI: https://doi.org/10.31004/edukatif.v3i6.948

Tabel.2 Kriteria Tingkat Validitas

\begin{tabular}{cc}
\hline Presentase & Kategori \\
\hline $100 \%-86 \%$ & Sangat Valid \\
\hline $85 \%-71 \%$ & Valid \\
\hline $70 \%-65 \%$ & Cukup Valid \\
\hline$<55 \%$ & Kurang Valid \\
\hline
\end{tabular}

Apabila presentase nilai dari validator kuesioner memenuhi kualifikasi baik/layak, maka tahap yang terakhir merupakan tahap evaluasi.

\section{HASIL DAN PEMBAHASAN}

Sebuah produk yang dihasilkan dari penelitian pengembangan ini ialah berupa sebuah aplikasi berupa media pembelajaran video animasi. Produk media pembelajaran ini dibuat sesuai dengan perkembangan anak usia dini, dengan tujuan agar dapat membantu guru dan orang tua dalam menyampaikan isi materi pembelajaran menghafal hadist khususnya pada anak kelompok B di TAAM/TPQ AL-ANWAR Depok Jawa Barat. Proses pembuatan media video animasi sebagai berikut :

\section{Analisi ( Analysis )}

Pada tahap analisis peneliti melaksanakan penganalisisan yang dapat untuk mengumpulkan informasi, pengumpulan informasi pada tahap ini dilakukan dengan cara observasi secara langsung pada TAAM/TPQ AL-ANWAR. Tujuan dilakukannya observasi ini sebagai acuan untuk membuat suatu produk media pembelajaran yang sesuai dengan kebutuhan di TAAM/TPD AL-ANWAR. Dari hasil analisis tersebut peneliti akan mengembangkan sebuah produk media pembelaran berupa media video animasi yang dapat digunakan untuk memudahkan serta meningkatkan menghafal hadist sejak dini. Media pembelajaran video animasi dapat diputar berulang-ulang agar memudahkan bagi pendidik untuk mengajar ke peserta didik. Media video animasi ini berupa kartun yang berisi cerita, gerakan serta arti perkata yang berkaitan dengan hadist tersebut, sehingga diharapkan anak mudah menghafal dan dapat mengimplementasikan dalam kehidupan sehariharinya.

\section{Desain ( Design )}

Pada tahap desain, peneliti mulai membuat skenario untuk media video animasi, skenario yang dirancang terdiri dari ide dasar, alur cerita, konflik, karakter tokoh, latar belakang dan tempat. Skenario dibuat berdasarkan dari kegiatan sehari-hari anak disekolah atau pun dirumah bersama teman-teman, guru, dan orang tuanya. Alur cerita dibuat dengan sederhana namun tetap dapat menyampaikan informasi mengenai hadisthadist yang disampaikan di video animasi kepada anak. setelah skenario selesai dibuat peneliti mulai mencari judul untuk video animasi. Lalu dilanjutkan dengan penyusunan storyboard untuk menyalurkan ide cerita dalam gambar secara tertulis untuk menvisualisasikan adegan dalam skenario.

Dalam kegiatan ini merupakan proses sistematik yang dimulai dari menetapkan tujuan belajar yakni memudahkan cara mengahafal hadist, merancang perangkat/media pembelajaran dengan didesign semenarik mungkin khususnya untuk kelompok anak usia 5-6 tahun dengan disertakan konten yang disukain anak seusianya yaitu dengan disisipin cerita yang mendukung isi/pesan dari hadist tersebut serta icon/simbol yang menarik buat anak. rancangan model/metode pembelajaran ini masih bersifat konseptual dan akan mendasari proses pengembangan berikutnya. 
3597 Pengembangan Media Video Animasi untuk Kemampuan Menghafal Hadist pada Anak Usia Dini - Siti Zahara, Benny Hendriana

DOI: https://doi.org/10.31004/edukatif.v3i6.948

\title{
ALUR CERITA
}

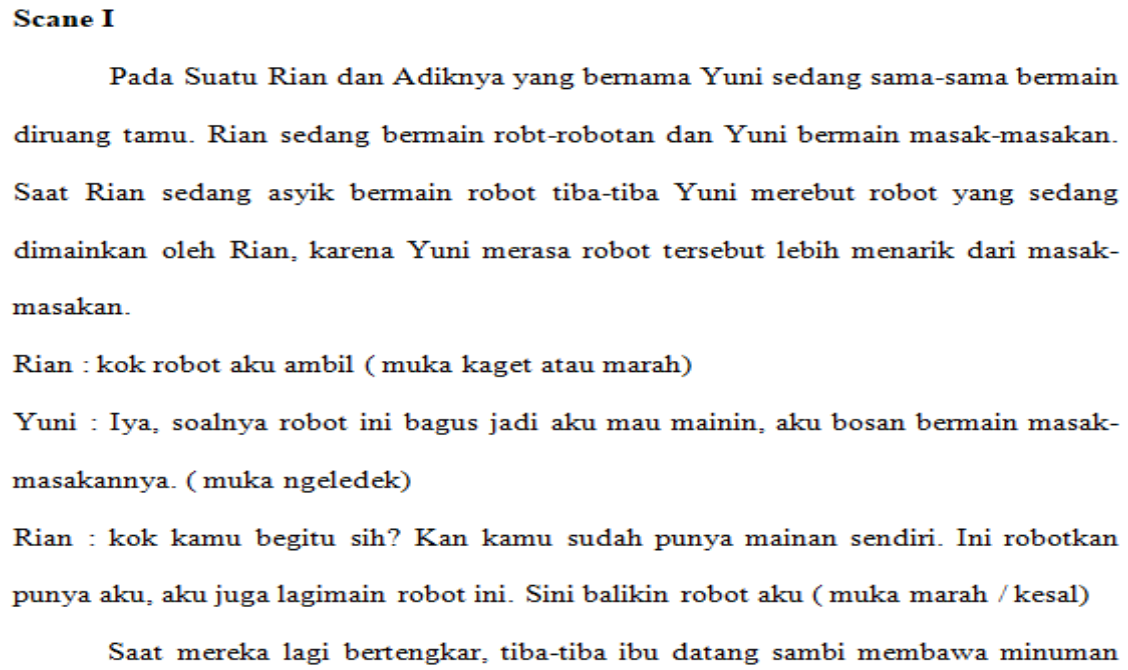

\section{Gambar 1: Skenario Media Video Animasi}

\section{Pengembangan ( Development)}

Tahap pengembangan ini merupakan tahapan yang dimana media pembelajaran video animasi menghafal hadist telah dibuat berdasarkan dengan desain atau storyboard yang telah dirancang. Setelah itu membuat instrument validasi produk untuk para ahli serta diuji cobakan kepada guru dan orang tua. Berikut proses pembuatan sebuah perangkat media pembelajaran berbasis media video animasi.

\section{VIDEO ANIMASI}

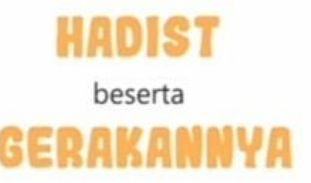

\author{
Rian \& Yuni
}

\section{Gambar 2: Judul Video Animasi}

Digambar ini menjelaskan tentang nama judul pada video tersebut.

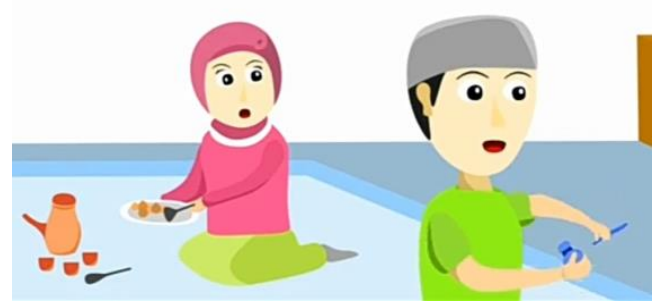

\section{Gambar 3: Sedang Bermain}

Pada gambar ini menjelaskan bahwa Rian dan Yuni sedang bermain Robot-robotan dan bermain masakmasakan bersama. 


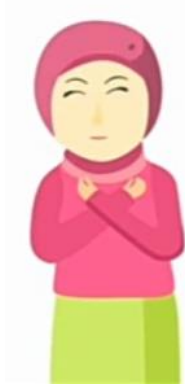

\section{"Laa" - JANGAN}

dengan mengangkat kedua tangan menyilang di Depan Dada

\section{Gambar 4: Membacakan Hadsit Larangan Marah}

Pada gambar yang ditampilkan Yuni sedang membacakan hadist larangan marah serta dengan gerakan dan terjemahannya. Dalam hadist tersebut dijelaskan bahwa kita tidak boleh marah-marah dikarenakan sudah ada mengenai hadistnya.

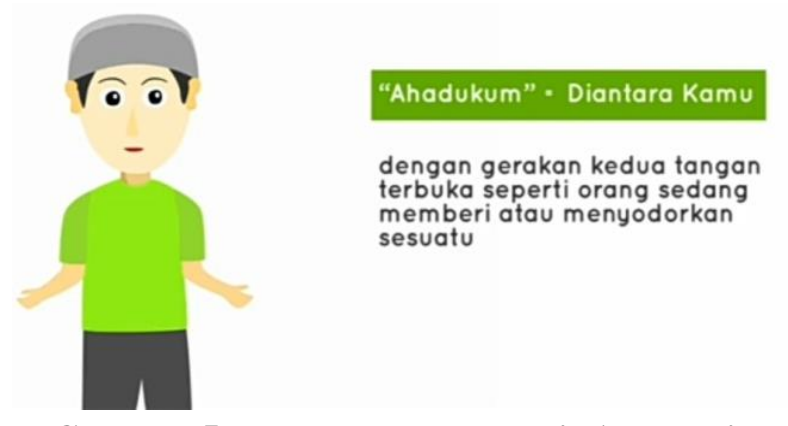

Gambar 5: Membacakan Hadsit Adab Minum

Pada tampilan gambar ini Rian sedang membacakan hadist adab minum, gambar di atas menjelaskan bahwa ketika minum tidak boleh sambil berdiri.

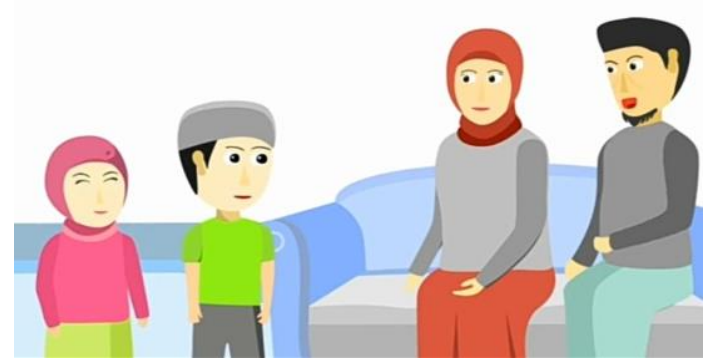

\section{Gambar 6: Sedang Memberikan Pemahaman Kepada Rian dan Yuni}

Pada tampilan gambar tersebut Rian dan keluarganya sedang duduk bersama diruang tamu sambil berdiskusi, ayah dan ibu menanyakan kepada Rian dan Yuni mengenai pengertian dalam sholat.

\section{"imaa duddilin" - Tiang Agama}

dengan mengangkat dan mengepalkan tangan

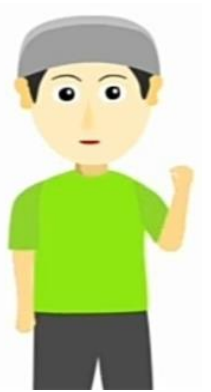




\section{Gambar 7: Membacakan Hadist Sholat}

Pada tampilan ini menjelaskan bahwa Rian sedang membacakan hadist sholat dengan cara tangan diangkat yaitu melambangkan bahwa sholat merupakan tiang agama dan sholat wajib dikerjakan oleh semua umat muslim.

\section{Implementasi ( Implemention )}

Setelah media yang dikembangkan telah selesai maka tahap selanjutnya yaitu pengimplentasian untuk dilakukannya validasi dan uji cobakan kepada anak, orang tua dan pendidik. Penguji validasi akan diberikan sebuah instrumen/ angket penilaian melalui google formulir, lalu orang tua dan pendidik akan diberikan kuesioner/angket penilaian yang telah disusun. Selanjutnya jika kuesioner/angket untuk para ahli, guru dan orang tua sudah siap selanjutnya akan diberikan penilaian menggunakan kriteria penilaian kuesioner/angket.

Hasil yang diperoleh dari masing-masing para ahli guru dan orang tua dapat dijadikan dalam tabel hasil uji kelayakan media pembelajaran seperti dibawah ini :

Tabel 3. Uji Kelayakan Media Pembelajaran

\begin{tabular}{ccc}
\hline Responden & Presentase & Keterangan \\
\hline Ahli Media & $90 \%$ & Sangat Valid \\
\hline Ahli Materi & $100 \%$ & Sangat Valid \\
\hline Ahli bAHASA & $87 \%$ & Sangar Valid \\
\hline $\begin{array}{c}\text { Guru TAAM/TPQ AL- } \\
\text { ANWAR }\end{array}$ & $77 \%$ & Valid \\
\hline Orang Tua Kelompok B & $86,9 \%$ & Sangat Valid \\
\hline
\end{tabular}

Hasil validasi dari ahli media mengenai penyajian media videa animasi dan tampilan menyeluruh dalam video animasi. Dari hasil yang diperleh validator ahli media mendapatkan presentase $90 \%$ dan sangat valid digunakan untuk media pembelajaran anak usia dini. Selanjutnya yaitu ahli validasi dari ahli materi mengenai kesesuaian media, manfaat media bagi anak, manfaat media untuk kegiatan pendidikan. Maka, dengan menggunakan kuesioner/angket sebagai alat ukur pengembangan media pembelajaran video animasi dapat divalidasi oleh ahi materi. Jadi berdasarkan hasil presentase yang di dapat $100 \%$ dan sangat valid digunakan pada pembelajaran anak usia dini.

Hasil validasi selanjutnya yaitu ahli bahasa yang berisi tentang kesesuaian bahasa yang digunakan dalam video animasimudah untuk dipahami anak usia dini, tata bahasa dalam video animasi dan ejaan yang gunakan EYD. Dari hasil perolehan penilaian validator ahli bahasa memperoleh hasil presentase sebesar $87 \%$ dan sangat valid digunakan untuk media pembelajaran anak usia dini. Selanjutnya hasil validasi yang digunakan oleh guru TAAM/TPQ AL-ANWAR Depok Jawa Barat, dengan menggunakan kuesioner berdasarkan hasil uji coba yang dilakukan oleh guru yang mengena isi materi yang dapat disampaikan dari video animasi, media pembelajaran mudah digunakan dalam pembelajaran, dan manfaat media untuk kegiatan belajar mengajar. Dilihat dari hasil kuesioner dari guru di TAAM/TPQ AL-ANWAR mendapat nilaidengan presentase $77 \%$ yang termasuk dalam kualifikasi valid. Dan selanjutnya hasil validasi terakhir yang dilakukan oleh orang tua kelompok B TAAM/TPQ AL-ANWAR mengenai media pembelajaran dapat menarik anak. bahasa yang digunakan mudah dipahami anak, dan dapat menambah pemahaman anaktentang hadist. dan dari hasil kuesioner orang tua kelompok B mendapat nilai presentasi $86,9 \%$ yang termasuk dalam kualitas sangat valid.

\section{Evaluasi ( Evaluation )}

Tahapan yang terakhir adalah evaluasi media pembelajaran video animasi menghafal hadist tahap ini merupakan tahapan untuk menganalisis kevalidan dan kelayakan serta mengetahui kelebihan dan kekurangan 
dari produk yang telah dikembangkan. Berdasarkan hasil penelitian pengembangan media video animasi untuk kemampuan menghafal hadist pada anak usia dini ini dapat dinayatakan layak,namun pada saat uji coba terhadap orang tua ada masukan mengenai suara tokoh, tanda baca hadistnya jelas, gambar dibuat lebih menarik dan kreatif.

Berdasarkan hasil validasi dan uji coba media video animasi untuk kemampuan mengahafal hadist dinyatakan layak untuk digunakan sebagai bahan ajar pengenalan hadist pada anak usia dini. Penelitian ini juga sejalan dengan hasil penelitian terdahulu yang telah dilakukan oleh (Malikhah, 2019) yang menghasilkan pengembangan cara menghafal hadist dengan metode gerakan dapat meningkatkan pemahaman anak usia dini. Ditambah juga dengan hasil penelitian terdahulu yang dilakukan oleh (Riqqoh et al., 2020) bahwa metode menirukan ucapan dan gerakan hadist dapat membuat anak lebih mudah menangkap hafalan dengan baik serta anak lebih semangat. Dengan demikian dapat dikatakan bahwa menghafal hadits dengan metode yang menyenangkan seperti dengan media video animasi yang peneliti kembangkan dapat lebih memudahkan anak dalam pembelajaran baik di sekolah dengan guru maupun di rumah dengan orang tua jarak jauh.

\section{KESIMPULAN}

Dari hasil penelitian pengembangan media video animasi dapat disimpulkan bahwa media dinyatakan sangat valid atau layak digunakan berdasarkan hasil penelitian dari validasi ahli dan uji coba media video animasi memberikan dampak positif, banyak manfaat yang dapat diperoleh dari media pembelajaran video animasi mengahafal hadist bagi anak usia dinj, guru, maupun orang tua. Dengan demikian disarankan guru untuk melakukan inovasi dalam mengembangkan media pembelajaran untuk anak dengan penggunaan teknologi.

\section{DAFTAR PUSTAKA}

Adriasa, I. N. M. (2021). Penerapan Metode Bercerita Dan Bernyanyi Untuk Meningkatkan Hasil Belajar Agama Hindu Siswa Kelas III Semester I SD Negeri 1 Dukuh. 4(2), 232-245.

Ani Wahyuni, Rame Santoso, \& Sidik. (2019). Animasi Interaktif Pembelajaran Tata Cara Shalat Untuk Paud Enggunakan Adobe Flash Cs 6.0. Journal Speedentra Penelitian Engineering Dan Edukasi (Speed), $11(4), 56-64$.

Anita Puji Astutik , Rahmania Sri Untari, A. M. P. (2021). Penggunaan Media Animasi "Muroja'ah For Kids" Untuk Meningkatkan Hafalan Anak. 6(4), 682-687.

Apriansyah, M. R. (2020). Pengembangan Media Pembelajaran Video Berbasis Animasi Mata Kuliah Ilmu Bahan Bangunan Di Program Studi Pendidikan Teknik Bangunan Fakultas Teknik Universitas Negeri Jakarta. Jurnal Pensil, 9(1), 9-18. Https://Doi.Org/10.21009/Jpensil.V9i1.12905

Indah Kemala Dewi, R. (2021). Penanaman Nilai Moral Pada Anak Usia Dini Oleh Orang Tua Dalam Keluarga Di Jorong Koto Alam. Pendidikan, 5(1), 56-65.

JANNAH, M., \& JULIANTO, J. (2018). Pengembangan Media Video Animasi Digestive System Untuk Meningkatkan Hasil Belajar Siswa Mata Pelajaran Ipa Kelas V. Jurnal Penelitian Pendidikan Guru Sekolah Dasar, 6(2), 254798.

Malikhah, F. (2019). Penerapan Metode Gerakan Untuk Menghafal Hadis Pada Anak. 4(1), 25-34.

Nasution, N. K. (2020). Perkembangan Anak Usia Dini (AUD) Di TK Aisyiyah: Problematika Dan Solusi. Jurnal Penelitian Keislaman, 15(2), 130-143. Https://Doi.Org/10.20414/Jpk.V15i2.1425

Oktapiani, M. (2020). Tingkat Kecerdasan Spiritual Dan Kemampuan Menghafal Al- Qur' An. Tadzhib Akhlak, 01, 96. 
3601 Pengembangan Media Video Animasi untuk Kemampuan Menghafal Hadist pada Anak Usia Dini - Siti Zahara, Benny Hendriana

DOI: https://doi.org/10.31004/edukatif.v3i6.948

Pratiwi, W. (2017). Konsep Bermain Pada Anak Usia Dini. Manajemen Pendidikan Islam, 5, 106-117. Retrieved From Https://Journal.Iaingorontalo.Ac.Id/Index.Php/Tjmpi/Article/View/395

Riqqoh, S., Syaiku, A., \& Mappapoleonro, A. M. (2020). Penerapan Pembelajaran Hafalan Hadits Pada Usia 5-6 Tahun. 142-154.

Safitri, L. N., \& 'Aziz, H. (2019). Pengembangan Nilai Agama Dan Moral Melalui Metode Bercerita Pada Anak. Golden Age: Jurnal Ilmiah Tumbuh Kembang Anak Usia Dini, 4(1), 85-96. Https://Doi.Org/10.14421/Jga.2019.41-08

Silawati, L., \& Syukri, M. (N.D.). Peningkatan Kemampuan Menghafal Surah Pendek Dengan Metode Drill Pada Anak Usia 4-5 Tahun. 1-12.

Tanfidiyah, N. (2017). Perkambangan Agama Dan Moral Yang Tidak Tercapai Pada AUD: Studi Kasus Di Kelas A1 TK Masyitoh Ndasari Budi Yogyakarta. Nadwa, 11(2), 199. Https://Doi.Org/10.21580/Nw.2017.11.2.1810

Wahyuningtyas, R., \& Sulasmono, B. S. (2020). Pentingnya Media Dalam Pembelajaran Guna Meningkatkan Hasil Belajar Di Sekolah Dasar. Edukatif: Jurnal Ilmu Pendidikan, 2(1), 23-27. Https://Doi.Org/10.31004/Edukatif.V2i1.77 